\title{
Orbital Sarcoma pT3 TNM Finding v8
}

National Cancer Institute

\section{Source}

National Cancer Institute. Orbital Sarcoma pT3 TNM Finding v8. NCI Thesaurus. Code C140845.

Orbital sarcoma with tumor of any size with invasion of bony walls. (from AJCC 8th Ed.) 